\title{
Prevalensi Telur Ascaris lumbricoides dan Trichuris trichiura pada Kotoran Kuku Tangan Murid Kelas I, II, dan III SD Negeri 013 Meranti Pandak Kecamatan Rumbai Pesisir Pekanbaru Serta Gambaran Faktor Risiko
}

\author{
Dwi Julianika Putri ${ }^{1}$, Suri Dwi Lesmana ${ }^{2}$, Tuti Restuastuti ${ }^{3}$
}

\begin{abstract}
Ascaris lumbricoides (A.lumbricoides ) and Trichuris trichiura ( T.trichiura ) are Soil Transmitted Helminth. Infection due to these worms still become a public health problem in Indonesia especially in students at elementary schools. The purpose of this research is to know the prevalence of students with positive A.lumbricoides and T.trichiura egg in their nail's dirt and the risk factors that affected it. Data was collected by questionaire and by examining the nail's dirt using Ismid's Modification Method to all of class I,II,III students with inclusion criteria (177 students ). The prevalence of students with positive A. lumbricoides dan T. trichiura eggs in nail dirt was $44.06 \%$ and $2.82 \%$. The prevalence of A.lumbricoides and T.trichiura are higher at boys (58.16\%), which are influenced by the parent's education and socio economical condition. The most cases was found in students with bad habit of family's toilet, hand washing after toilet, often play in ground, and the habit of nail-cutting.
\end{abstract}

Keywords: : A.lumbricoides, T.trichiura, prevalence, nail's dirt, risk factors.

Penyakit yang disebabkan oleh infeksi cacing yang ditularkan melalui tanah (Soil Transmitted Helminthes) merupakan salah satu masalah kesehatan yang serius di negara berkembang. ${ }^{1}$ Komplikasi akibat dari penyakit tersebut dapat berupa gangguan gizi, anemia, gangguan pertumbuhan, gangguan kecerdasan dan lain-lain. ${ }^{2}$

Soil Transmitted Helminthes (STH) yang paling banyak ditemukan dan menimbulkan penyakit diantaranya Ascaris lumbricoides ( $A$. lumbricoides), Trichuris trichiura (T. trichuira), dan kelompok cacing tambang yaitu Ancylostoma duodenale (A. duodenale) dan Necator americanus (N. americanus). Jenis cacing ini tersebar di seluruh

\footnotetext{
1. Fakultas Kedokteran Universitas Riau

2. Penulis untuk korespondensi: Bagian Parasitologi Kedokteran Fakultas Kedokteran Universitas Riau, Alamat: Jl.Diponegoro No.1, Pekanbaru. Telp: 0761- 839264 ext 209.

3. Bagian Ilmu Kesehatan Masyarakat-Kedokteran Komunitas FK Unri
}

dunia dan angka kejadian terbanyak dijumpai pada anak-anak. ${ }^{3}$ Prevalensi STH di dunia pada tahun 2005 mencakup 14,28\% kasus A. lumbricoides, $12,85 \%$ kasus $A$. duodenale dan $7,14 \%$ kasus $T$. trichiura. ${ }^{1}$

Infeksi STH di Indonesia masih cukup tinggi dengan prevalensi paling banyak terdapat di pedesaan. Data menyebutkan bahwa $60 \%$ penduduk Indonesia terinfeksi cacing, dengan $21 \%$ diantaranya menyerang anak usia Sekolah Dasar (SD). ${ }^{3}$ Penelitian Saprasetya ${ }^{4}$ di Banyumas pada anak 1 - 9 tahun didapatkan masing-masing infeksi $A$. lumbricoides $90 \%$, T. trichiura $88 \%$, dan cacing tambang $13 \%$.

Riau merupakan salah satu daerah dengan angka infeksi STH yang tinggi, hal ini sesuai dengan hasil survei prevalensi STH pada tahun 2004 di Riau dilaporkan A. lumbricoides $40,00 \%$ dan $T$. trichiura $29,83 \% .{ }^{5}$ Tingginya prevalensi ini disebabkan oleh sanitasi lingkungan yang kurang baik, pengetahuan masyarakat tentang kesehatan 
yang masih rendah dan perilaku masyarakat khususnya anak - anak yang suka bermain di tanah dan tidak membiasakan mencuci tangan sesudah buang air besar dan bermain tanah, buang air besar tidak pada tempatnya dan kurangnya perhatian terhadap kebersihan kuku. ${ }^{5}$

Infeksi A. lumbricoides dan T. trichuira ditularkan melalui mulut. Salah satu media transmisi telur A. lumbricoides dan T. trichuira terjadi melalui perantaraan kotoran kuku yang mengandung telur A. lumbricoides dan T. trichiura yang infektif. Telur A. lumbricoides dan T. trichuira yang tertelan dapat tumbuh menjadi cacing dewasa dalam tubuh manusia dan berkembang biak dengan mengeluarkan banyak telur. ${ }^{6}$ Rahayu ${ }^{7}$ pada tahun 2004 melakukan penelitian terhadap potongan kuku siswa SD di Malang, didapatkan frekuensi telur $A$. lumbricoides $65,22 \%$ dan $T$. trichiura sebesar 11,59\%. Penelitian Gusrianti ${ }^{8}$ tahun 2001 pada murid SD negeri No.15 Kabupaten Agam didapatkan frekunsi murid yang positif telur $A$. lumbricoides dalam kotoran kuku sebesar 25\%, dengan frekuensi yang lebih besar didapat pada anak laki-laki. Riani ${ }^{9}$ pada tahun 2008 melakukan pemeriksaan kuku terhadap 24 siswa Madrasah Ibtidaiyah Bustanul Ulum (MIBU) Glengseran Kecamatan Panti Kabupaten Jember didapatkan 8 orang positif mengandung cacing usus, diantaranya 6 siswa (75\%) positif $A$. lumbricoides dan 3 siswa (37,5\%) positif $T$.trichuira.

Berdasarkan data dari kelurahan dan observasi yang dilakukan oleh peneliti, Meranti Pandak Kecamatan Rumbai Pesisir merupakan salah satu daerah di Pekanbaru yang rawan dengan infeksi $A$. lumbricoides dan T. trichuira, hal ini dikarenakan Meranti Pandak mempunyai kondisi lingkungan yang kotor, jenis tanah yang cocok dengan habitat telur A. lumbricoides dan T. trichuira yaitu di tanah liat, penduduk dengan pemukiman yang padat, dan tingkat sosial ekonomi penduduk yang rendah serta memiliki kebiasaan membuang hajat (defekasi) di tanah, yang kemudian tanah akan terkontaminasi dengan telur cacing yang infektif. Sekolah Dasar (SD) Negeri 013 merupakan salah satu SD yang berlokasi di Meranti Pandak. Kebanyakan anak-anak yang bersekolah di sana mempunyai kebiasaan bermain di tanah, sehingga memudahkan cacing atau telur cacing melakukan kontak langsung dengan tangan dan akhirnya masuk ke dalam kuku. Hal ini lebih berisiko terjadi pada anak SD kelas I, II, dan III, karena anak tersebut belum bisa memperhatikan kebersihan dirinya sendiri dan kebanyakan mereka masih suka bermain di tanah seperti bermain kelereng, dan lain-lain. Penelitian Agus ${ }^{10}$ tahun 2005 melalui pemeriksaan tinja Murid SD Kelurahan Meranti Pandak menunjukkan angka infeksi A.lumbricoides yang cukup tinggi (30,47\%).

Banyak faktor yang mempengaruhi keberadaan telur A.lumbricoides dan T. trichiura, antara lain tingkat pendidikan, status ekonomi, kebiasaan mencuci tangan setelah bermain di tanah dan buang air besar, penggunaan jamban dan kebiasaan memotong kuku teratur.

Berdasarkan hal-hal yang diuraikan di atas, maka peneliti tertarik memeriksa kotoran kuku untuk melihat dan mengetahui prevalensi telur $A$. lumbricoides dan T. trichuira melalui pemeriksaan kotoran kuku tangan pada anak-anak yang ada di SD Negeri 013 Meranti Pandak Kecamatan Rumbai Pesisir serta mengetahui faktor-faktor resikonya.

\section{METODE}

Penelitian ini adalah penelitian deskriptif yang dilakukan untuk identifikasi telur A.lumbricoides dan T.trichiura pada kotoran kuku dan mengetahui faktor risiko terinfeksi telur A.lumbricoides dan T.trichiura melalui kuesioner, tanpa menganalisis hubungan antara keberadaan telur cacing dengan faktor risiko tersebut. Waktu pengumpulan data penelitian dilaksanakan pada bulan Februari 2009. Lokasi penelitian adalah SD Negeri 013 Meranti Pandak Kecamatan Rumbai Pesisir Kota Pekanbaru. Identifikasi telur A.lumbricoides dan T.trichiura dilakukan di Laboratorium Parasitologi Fakultas Kedokteran Universitas Riau.

Populasi penelitian adalah seluruh murid kelas I, II, dan III SD Negeri 013 Meranti Pandak Kecamatan Rumbai Pesisir Kota Pekanbaru. Sampel adalah murid kelas I, II dan III yang berkuku panjang dari masing-masing kelas. Sampel diperoleh dengan metode Total Sampling.

Tahap pertama dilakukan penjelasan untuk menerangkan tujuan penelitian ini pada guru dan murid SD. Setelah itu dilakukan pengumpulan sampel secara bertahap mulai dari murid kelas I, II, dan III. Pemotongan kuku dilakukan oleh peneliti 
sendiri. Kotoran kuku yang telah dipotong dimasukkan ke dalam kertas minyak yang telah diberi label untuk masing-masing anak. Seluruh kotoran kuku dibawa ke Laboratorium Parasitologi Kedokteran Universitas Riau untuk diperiksa menurut cara Modifikasi Ismid. ${ }^{11}$ Kuesioner dibagikan pada murid yang dipotong kukunya, kemudian kuesioner diisi oleh orang tua murid dan diserahkan keesokan harinya kepada peneliti. Bahan dan alat yang digunakan terdiri dari: kertas minyak, pipet, kaca objek, cawan petri, tabung sentrifuse, alat sentrifuse, gunting kuku, mikroskop, deck glass, potongan kuku, larutan $\mathrm{NaOH} 0,23 \%$.

Cara kerja metode modifikasi Ismid ${ }^{8}$ adalah memasukkan potongan kuku ke dalam tabung sentrifus yang ditambahkan $5 \mathrm{ml}$ larutan $\mathrm{NaOH}$ $0,23 \%$. Setelah dikocok kuat selama 5 menit, cairan dituangkan ke cawan petri dan potongan kuku dikeluarkan. Kemudian cairan_dimasukkan kembali ke dalam tabung sentrifus dan diputar pada kecepatan $2000 \mathrm{rpm}$ selama 2 menit. Cairan supernatan dibuang dan sedimen yang berisi spesimen diambil dengan pipet, lalu diteteskan pada kaca benda dan ditutup dengan kaca penutup. Sediaan diperiksa di bawah mikroskop dengan pembesaran $10 \times 10$, dan dinyatakan positif bila dalam sediaan ditemukan telur cacing dan negatif bila tidak. Pemeriksaan spesimen dilakukan sampai sedimen yang diperoleh habis. Selanjutnya sampel yang dinyatakan positif tersebut diberi kode 1 , sedangkan sampel yang dinyatakan negatif diberi kode 0 . Selanjutnya mengidentifikasi telur-telur cacing parasit yang ditemukan. Identifikasi dilakukan berdasar pada bentuk, ukuran, warna, dan ciri khas dindingnya, Menghitung semua jenis telur cacing parasit yang ditemukan pada semua stadium A. lumbricoides (dibuahi, tidak dibuahi, dekortifikasi) dan telur T. trichiura yang bentuknya seperti tempayan, Bila pemeriksaan dan identifikasi telur belum selesai dilakukan pada hari pertama, maka sedimen diawetkan dengan larutan fiksatif formalin $10 \%$, Kemudian data yang diperoleh disajikan dalam bentuk tabel dan narasi.

Hasil laboratorium kemudian digabung dengan kuesioner untuk kemudian dikelompokkan berdasarkan status ekonomi, pendidikan orang tua, penggunaan jamban, kebiasaan makan, kebiasaan bermain tanah, kebiasaan mencuci tangan sesudah buang air besar dan setelah bermain di tanah, serta kebiasaan memotong kuku murid SD Negeri 013 Meranti Pandak Kecamatan Rumbai Pesisir Kota Pekanbaru kelas I, II, dan III. Tingkat pendidikan orang tua dibagi menjadi rendah (SD atau SMP sederajat), sedang (SMA sederajat) dan tinggi (setidaknya diploma). Status ekonomi dikategorikan atas rendah (penghasilan kurang dari Rp 500.000 per bulan), menengah rendah (Rp 500.000 2.000 .000 per bulan), menengah tinggi ( $\mathrm{Rp}$ $2.000 .000-6.000 .000$ perbulan) dan tinggi (lebih Rp 6.000.000 per bulan). Kebiasaan buang air besar dibagi menjadi baik ( buang air besar di jamban/wc di rumah), tidak baik (buang air besar di tanah/parit/ sungai). Kebiasaan mencuci tangan setelah buang air besar dibagi atas baik (mencuci tangan dengan sabun sesudah buang air besar), dan tidak baik (tidak mencuci tangan atau mencuci tangan tidak dengan sabun setelah buang air besar). Kebiasaan main di tanah dikategorikan atas baik (tidak bermain di tanah) dan tidak baik (bermain di tanah). Kebiasaan mencuci tangan dibagi atas baik (mencuci tangan dengan sabun sesudah bermain di tanah) dan tidak baik (mencuci tangan tanpa sabun sesudah bermain di tanah dan tidak mencuci tangan sesudah bermain di tanah). Kebiasaan memotong kuku dibagi atas baik (memotong kuku sekali seminggu) dan tidak baik (memotong kuku lebih dari seminggu). Selanjutnya Data yang diperoleh diolah secara manual dan disajikan dalam bentuk tabel dan narasi.

\section{HASIL}

Responden adalah murid SD Negeri 013 Meranti Pandak Kecamatan Rumbai Pesisir Kota Pekanbaru Kelas I, II, III. Jumlah murid keseluruhan dari kelas I sampai III adalah 249 orang, dengan jumlah laki-laki dan perempuan 135 orang dan 114 orang. Berdasarkan hasil kuesioner, sebagian besar responden mempunyai tingkat pendidikan orang tua yang tergolong rendah yaitu SD dan SMP sederajat (94 orang) dan status ekonomi keluarga yang tergolong menengah rendah (108 orang). Murid yang hadir pada saat pemeriksaan 232, yang tidak berkuku panjang 55 orang, sehingga sampel penelitian 177 orang dengan jumlah laki-laki 98 orang dan perempuan 79 orang. Seluruh sampel yang diperiksa didapatkan 78 orang $(44,06 \%)$ positif mengandung telur $A$. lumbricoides, 5 orang $(2,82 \%)$ positif mengandung telur $T$.trichiura, tidak 
ditemukan campuran telur A. lumbricoides dan $T$ .trichiura dan 94 orang murid tidak mengandung telur A. lumbricoides maupun T. trichiura dalam kotoran kukunya.
Berdasarkan kuesioner dan hasil pemeriksaan kuku, prevalensi telur A. lumbricoides dan $T$. trichiura pada murid SD Negeri 013 Meranti Pandak Kecamatan Rumbai Pesisir Kota Pekanbaru berdasarkan jenis kelamin dapat dilihat dalam Tabel 1 sebagai berikut:

Tabel 1. Distribusi Prevalensi Telur A. lumbricoides dan T. trichiura pada Kotoran Kuku Murid SD Negeri 013 Meranti Pandak Kecamatan Rumbai Pesisir Kota Pekanbaru Berdasarkan Jenis Kelamin

\begin{tabular}{|c|c|c|c|c|c|c|c|c|c|}
\hline \multirow[t]{2}{*}{ Jenis Kelamin } & \multirow[t]{2}{*}{ Jumlah } & \multicolumn{2}{|c|}{ Positif Al } & \multicolumn{2}{|c|}{ Positif Tt } & \multicolumn{2}{|c|}{$\begin{array}{l}\text { Positif } \\
\mathrm{A} 1+\mathrm{Tt}\end{array}$} & \multicolumn{2}{|c|}{$\begin{array}{l}\text { Negatif } \\
\text { A1 \& Tt }\end{array}$} \\
\hline & & $\mathrm{n}$ & $\%$ & $\mathrm{~N}$ & $\%$ & $\mathrm{n}$ & $\%$ & $\mathrm{n}$ & $\%$ \\
\hline Laki-laki & 98 & 57 & 58,16 & 4 & 4,08 & 0 & 0 & 37 & 37,76 \\
\hline Perempuan & 79 & 21 & 26,58 & 1 & 1,27 & 0 & 0 & 57 & 72,15 \\
\hline Jumlah & 177 & 78 & 44,06 & 5 & 2,82 & 0 & 0 & 94 & 53,10 \\
\hline
\end{tabular}

Berdasarkan kuesioner dan hasil pemeriksaan kotoran kuku, prevalensi telur A. lumbricoides dan T. trichiura pada murid SD Negeri 013 Meranti
Pandak Kecamatan Rumbai Pesisir Kota Pekanbaru berdasarkan tingkat pendidikan orang tua dapat dilihat dalam Tabel 2 sebagai berikut:

Tabel 2. Distribusi Prevalensi Telur A. lumbricoides dan T. trichiura pada Kotoran Kuku Murid SD Negeri 013 Meranti Pandak Kecamatan Rumbai Pesisir Kota Pekanbaru Berdasarkan Tingkat Pendidikan Orang Tua

\begin{tabular}{cccccccccc}
\hline \multirow{2}{*}{$\begin{array}{c}\text { Tingkat } \\
\text { Pendidikan }\end{array}$} & \multirow{2}{*}{ Jumlah } & \multicolumn{2}{c}{ Positif Al } & \multicolumn{2}{c}{ Positif Tt } & \multicolumn{2}{c}{$\begin{array}{c}\text { Positif } \\
\mathrm{A} 1+\mathrm{Tt}\end{array}$} & \multicolumn{2}{c}{$\begin{array}{c}\text { Negatif } \\
\mathrm{A1} \& \mathrm{Tt}\end{array}$} \\
\cline { 2 - 10 } & & $\mathrm{n}$ & $\%$ & $\mathrm{n}$ & $\%$ & $\mathrm{n}$ & $\%$ & $\mathrm{n}$ & $\%$ \\
\hline Rendah & 94 & 51 & 54,25 & 4 & 4,26 & 0 & 0 & 39 & 41,49 \\
Sedang & 75 & 26 & 34,67 & 1 & 1,33 & 0 & 0 & 48 & 64,00 \\
Tinggi & 8 & 1 & 12,50 & 0 & 0 & 0 & 0 & 7 & 87,50 \\
Jumlah & 177 & 78 & 44,08 & 5 & 2,82 & 0 & 0 & 94 & 53,10 \\
\hline
\end{tabular}

Berdasarkan kuesioner dan hasil pemeriksaan kotoran kuku, prevalensi telur A. lumbricoides dan T. trichiura pada murid SD Negeri 013 Meranti
Pandak Kecamatan Rumbai Pesisir Kota Pekanbaru berdasarkan status ekonomi keluarga dapat dilihat dalam Tabel 3 sebagai berikut:

Tabel 3. Distribusi Prevalensi Telur A. lumbricoides dan T. trichiura pada Kotoran Kuku Murid SD Negeri 013 Meranti Pandak Kecamatan Rumbai Pesisir Kota Pekanbaru Berdasarkan Status Ekonomi Keluarga

\begin{tabular}{cccccccccc}
\hline & & \multicolumn{2}{c}{ Positif Al } & \multicolumn{2}{c}{ Positif Tt } & \multicolumn{2}{c}{ Positif } & \multicolumn{2}{c}{ Negatif } \\
Status Ekonomi & Jumlah & \multicolumn{2}{c}{ Tt } & \multicolumn{2}{c}{ A1 \& Tt } \\
& & $\mathrm{n}$ & $\%$ & $\mathrm{n}$ & $\%$ & $\mathrm{~N}$ & $\%$ & $\mathrm{n}$ & $\%$ \\
\hline Rendah & 67 & 40 & 59,70 & 5 & 7,46 & 0 & 0 & 22 & 32,84 \\
Menengah rendah & 108 & 38 & 35,18 & 0 & 0 & 0 & 0 & 70 & 64,82 \\
Menengah Tinggi & 2 & 0 & 0 & 0 & 0 & 0 & 0 & 2 & 100 \\
Tinggi & 0 & 0 & 0 & 0 & 0 & 0 & 0 & 0 & 0 \\
\hline Jum1ah & 177 & 78 & 44,06 & 5 & 2,82 & 0 & 0 & 94 & 53,10 \\
\hline
\end{tabular}


Faktor risiko yang dinilai dalam penelitian ini antara lain tempat buang air besar, kebiasaan cuci tangan setelah buang air besar, kebiasaan bermain di tanah, kebiasaan mencuci tangan setelah bermain di tanah serta kebiasaan memotong kuku. Penilaian terhadap faktor-faktor risiko tersebut didapat dari pengisian kuesioner penelitian oleh responden, selanjutnya ditampilkan dalam tabel distribusi frekuensi berikut:

Tabel 4. Distribusi Prevalensi Telur A. lumbricoides dan T. trichiura pada Kotoran Kuku Murid SD Negeri 013 Meranti Pandak Kecamatan Rumbai Pesisir Kota Pekanbaru Berdasarkan Faktor Risiko

\begin{tabular}{|c|c|c|c|c|c|c|c|c|c|}
\hline \multirow[t]{2}{*}{ Faktor Risiko } & \multirow[t]{2}{*}{ Jumlah } & \multicolumn{2}{|c|}{ Positif A1 } & \multicolumn{2}{|c|}{ Positif Tt } & \multicolumn{2}{|c|}{$\begin{array}{l}\text { Positif } \\
\mathrm{A} 1+\mathrm{Tt}\end{array}$} & \multicolumn{2}{|c|}{$\begin{array}{l}\text { Negatif } \\
\text { A1 \& Tt }\end{array}$} \\
\hline & & $\mathrm{n}$ & $\%$ & $\mathrm{n}$ & $\%$ & $\mathrm{~N}$ & $\%$ & $\mathrm{n}$ & $\%$ \\
\hline $\begin{array}{l}\text { Tempat BAB } \\
\text { Baik }\end{array}$ & 164 & 69 & 42,08 & 2 & 1,21 & 0 & 0 & 93 & 56,71 \\
\hline Tidak baik & 13 & 9 & 69,23 & 3 & 23,08 & 0 & 0 & 1 & 7,69 \\
\hline $\begin{array}{l}\text { Kebiasaan Cuci Tangan } \\
\text { Setelah BAB } \\
\text { Baik }\end{array}$ & 115 & 35 & 30,44 & 2 & 1,74 & 0 & 0 & 78 & 67,82 \\
\hline Tidak baik & 62 & 43 & 69,35 & 3 & 4,84 & 0 & 0 & 16 & 25,81 \\
\hline $\begin{array}{l}\text { Kebiasaan Bermain di } \\
\text { Tanah } \\
\text { Ya }\end{array}$ & 86 & 45 & 52,32 & 5 & 5,82 & 0 & 0 & 36 & 41.86 \\
\hline Tidak & 91 & 33 & 36,26 & 0 & 0 & 0 & 0 & 58 & 63,74 \\
\hline $\begin{array}{l}\text { Kebiasaan Cuci Tangan } \\
\text { Setelah Bermain di Tanah } \\
\text { Baik }\end{array}$ & 86 & 45 & 52,32 & 5 & 5,82 & 0 & 0 & 36 & 41,86 \\
\hline Tidak baik & 91 & 33 & 36,26 & 0 & 0 & 0 & 0 & 58 & 63,74 \\
\hline $\begin{array}{l}\text { Kebiasaan Potong Kuku } \\
\text { Baik }\end{array}$ & 128 & 41 & 3203 & 7 & 156 & 0 & 0 & 05 & 4 \\
\hline Tidak baik & 49 & 37 & 75,51 & 3 & 6,12 & 0 & 0 & 9 & 18,37 \\
\hline
\end{tabular}

\section{PEMBAHASAN}

Berdasarkan tabel 1 didapatkan prevalensi $A$. lumbricoides dan T. trichiura pada murid laki-laki lebih tinggi daripada murid perempuan. Hal ini sama dengan penelitian yang dilakukan oleh Gusrianti ${ }^{8}$ yang melakukan pemeriksaan kotoran kuku terhadap murid SD Negeri 15 Limo Kampuang Kecamatan Banuhampu Sei Puar Kabupaten Agam, dimana pada murid laki-laki $(25,58 \%)$ lebih tinggi daripada murid perempuan (24,32\%). Menurut Brown (dikutip dari Gusrianti), tingginya angka pada murid 
laki-laki dikarenakan mereka lebih sering bermain di luar rumah. ${ }^{8}$

Berdasarkan kuesioner dan hasil pemeriksaan kotoran kuku murid SD Negeri 013 Meranti Pandak Kecamatan Rumbai Pesisir Kota Pekanbaru didapatkan $54,25 \%$ dan $4,25 \%$ murid yang positif mengandung telur $A$. lumbricoides dan T. trichiura di dalam kotoran kukunya memiliki orang tua dengan tingkat pendidikan rendah. Penelitian yang dilakukan oleh Agus ${ }^{10}$ melalui pemeriksaan tinja pada murid SD Negeri 034 Meranti Pandak didapat $76,92 \%$ yang terinfeksi cacingan berasal dari orang tua yang berpendidikan rendah dan oleh Elmi ${ }^{2}$ di Sumatera Utara didapat 81,3\% anak yang terinfeksi STH berasal dari orang tua yang berpendidikan rendah. Tingkat pendidikan yang rendah menyebabkan kurangnya kesadaran tentang pentingnya menjaga kebersihan diri terutama kuku dan terbatasnya pengetahuan bahwa kuku yang panjang dan kotor dapat menjadi media penularan infeksi cacing.

Berdasarkan kuesioner dan hasil pemeriksaan kotoran kuku murid SD Negeri. 013 Meranti Pandak Kecamatan Rumbai Pesisir Kota Pekanbaru didapatkan $59,70 \%$ murid yang positif mengandung telur A. lumbricoides di dalam kotoran kukunya memiliki keluarga dengan status ekonomi rendah. Keseluruhan murid yang positif telur T. trichiura memiliki keluarga dengan status ekonomi rendah. Berdasarkan hasil penelitian yang dilakukan oleh Agus $^{10}$ melalui pemeriksaan tinja pada murid SD negeri 034 Meranti Pandak didapat 84,61\% murid yang terinfeksi cacingan terdapat pada keluarga dengan status ekonomi rendah. Kemiskinan dapat mengurangi kemampuan keluarga untuk memenuhi kebutuhan hidup, dengan penghasilan keluarga yang rendah cenderung pendidikan dalam keluarga tersebut rendah dan menyebabkan semakin kurangnya pengetahuan tentang pentingnya menjaga kebersihan diri seperti cuci tangan dan memotong kuku teratur.

Hasil penelitian menunjukkan sebagian besar murid positif telur A.lumbricoides dalam kotoran kukunya mempunyai tempat BAB yang baik. Hasil penelitian sebelumnya yaitu penelitian yang dilakukan Widyanigsih ${ }^{12}$ pada anak sekolah dasar di Kabupaten Karanganyar, menemukan bahwa terdapat hubungan antara tempat $\mathrm{BAB}$ responden dengan infeksi cacing, namun hasil penelitian Rio ${ }^{11}$ menyebutkan bahwa sebagian besar $(84,35 \%)$ murid SDN Labuhan Tangga Besar yang terinfeksi STH mempunyai tempat BAB yang baik.

Hasil penelitian yang didapatkan tidak sesuai dengan semestinya, dimana sanitasi yang baik tidak sejalan dengan infeksi cacing tersebut. Hal ini kemungkinan disebabkan adanya kecenderungan responden menjawab telah $\mathrm{BAB}$ di jamban dalam pengisian kuesioner dan adanya faktor lain seperti kebiasaan memotong kuku, jajan di luar rumah dan faktor kebersihan personal. Berdasarkan hasil observasi tempat $\mathrm{BAB}$ banyak dijumpai murid yang memiliki jamban yang tidak sehat dan tidak memenuhi syarat-syarat yang baik yaitu jarak antara jamban dan tempat tinggal minimal $10 \mathrm{~m}$ dari rumah dan setiap jamban harus mempunyai tempat penampungan untuk tinja. ${ }^{13}$

Murid yang positif telur T. Trichiura sebagian besar memiliki tempat BAB yang tidak baik. Hal ini sejalan dengan penelitian Widyanigsih ${ }^{12}$ yang menemukan hubungan antara tempat $\mathrm{BAB}$ responden dengan infeksi cacing. Tempat $\mathrm{BAB}$ yang tidak baik akan semakin memudahkan terjadinya penularan mengingat jalur masuknya telur cacing tersebut ke tubuh manusia adalah melalui rute fecal oral.

Hasil penelitian menunjukkan bahwa sebagian besar murid yang positif telur A.lumbricoides maupun T.trichiura mempunyai kebiasaan cuci tangan setelah BAB yang tidak baik Kebiasaan tidak mencuci tangan dengan baik setelah $\mathrm{BAB}$ tersebut merupakan salah satu faktor risiko yang bisa mempermudah adanya telur A. lumbricoides dan $T$. trichiura, hal ini disebabkan karena adanya kemungkinan masuknya telur cacing ke dalam kuku setelah $\mathrm{BAB}$, jadi seandainya tidak dicuci dengan baik maka akan ada kemungkinan masuknya telur cacing di kuku tersebut ke dalam tubuh dan akhirnya menimbulkan infeksi. Tangan yang kotor karena menyentuh feses mengandung cacing maupun telur cacing, kurang lebih 10 juta virus, dan 1 juta bakteri. ${ }^{14}$

Sebagian besar murid yang positif telur A.lumbricoides maupun T.trichiura mempunyai kebiasaan bermain di tanah. Hal tersebut sejalan dengan penelitian Widyaningsih ${ }^{32}$ yang menemukan pada anak yang terinfeksi STH sebagian besar 
mempunyai kebiasaan bermain di tanah. Anak-anak yang bermain di tanah lebih mudah kontak dengan dengan telur cacing dibandingkan dengan yang tidak bermain di tanah. Telur cacing akan masuk melalui kuku, dan apabila anak tidak mencuci tangan sebelum makan dan sesudah bermain di tanah akan memudahkan telur yang ada di kuku masuk ke dalam tubuh manusia melalui mulut.

Hasil penelitian menunjukkan sebagian besar murid yang mengandung telur $A$. lumbricoides dan T. trichiura dalam kotoran kukunya mempunyai kebiasaan cuci tangan setelah bermain di tanah yang baik Hasil penelitian ini dapat menunjukkan bahwa sebagian besar murid telah mempunyai pengetahuan yang cukup tentang pentingnya mencuci tangan, tetapi kemungkinan prosedur cuci tangan yang dilakukan belum benar.

Murid yang mengandung telur A. lumbricoides dalam kotoran kukunya sebagian besar mempunyai kebiasaan potong kuku yang baik, begitu juga dengan murid yang mengandung telur T. trichiura. Kuku panjang yang jarang dipotong dapat menjadi tempat beradanya telur-telur A. lumbricoides dan $T$. trichiura. Penelitian yang dilakukan oleh Widyaningsih ${ }^{12}$ pada anak SD di Desa tertinggal dan Desa non tertinggal Kec. Tasik Madu Kab.Karanganyar menunjukkan hubungan antara kebiasaan potong kuku dengan infeksi STH.

Hal ini tidak sesuai dengan semestinya dimana kebiasaan hiegiene perorangan tidak sesuai dengan perkembangan infeksi kecacingan. Ini disebabkan karena banyak faktor yang berpengaruh terhadap tingginya angka infeksi cacingan. Kebiasaan makan jajanan yang dijual dipinggir-pinggir jalan sangat berpengaruh terhadap tingginya angka infeksi pada anak usia sekolah karena anak usia sekolah suka membeli jajanan yang dijual dipinggir jalan yang kebersihannya tidak diperhatikan oleh penjualnya sehingga makanan tersebut dapat mengandung telur cacing yang infektif yang dibawa oleh lalat ke makanan yang dijual. Selain itu angka infeksi juga bisa disebabkan karena frekuensi bermain anak-anak yang tinggi ditanah dan sekitar sungai maka bisa memungkinkan banyak debu-debu tanah yang mengandung telur cacing yang infektif yang terhirup dan tertinggal di pakaian sehingga lengket ke kulit dan termakan oleh anak-anak tersebut. Guru juga sangat berperan dalam tersebut. Kurangnya kesadaran guru untuk rutin memeriksa kuku murid juga akan menyebabkan murid tidak disiplin untuk memotong kuku sehingga kotoran kuku termasuk telur cacing akan terkumpul di bawah kuku yang akan menginfeksi murid.

\section{KESIMPULAN}

Prevalensi keberadaan telur A. lumbricoides pada kotoran kuku murid SDN 013 Meranti Pandak tinggi dan ditemukan juga beberapa sampel yang positif telur T.trichiura. Frekuensi telur A.lumbricoides dan T.trichiura lebih tinggi pada murid laki-laki, pada orang tua dengan tingkat pendidikan rendah, pada keluarga yang status ekonomi rendah, pada murid dengan kebiasaan $\mathrm{BAB}$ tidak pada jamban, pada murid yang tidak mencuci tangannya dengan baik setelah BAB, murid yang suka bermain di tanah, murid yang mempunyai kebiasaan cuci tangan yang baik setelah bermain di tanah, dan pada murid yang mempunyai kebiasaan potong kuku lebih dari 1 minggu sekali.

\section{UCAPAN TERIMAKASIH}

Penulis mengucapkan terimakasih kepada Dekan FK Unri dan rekan-rekan yang telah banyak membantu terutama di bagian Parasitologi FK Unri serta pihak Sekolah Dasar Negeri 013 Meranti Pandak Kecamatan Rumbai Pesisir Pekanbaru yang bersedia membantu pelaksanaan penelitian ini.

\section{DAFTAR PUSTAKA}

1. World Health Organization (WHO). The Risk of Ascaris lumbricoides infection in children as an environmenivital health indicator to guide preventive activities in Caparo and Alto Caparao, Brazil. 2002. [diakses 15 September 2008]. Diunduh dari : http:// whqlibdoc. Who.int // bulletin.

2. Elmi, Sembiring T, Dewiyani BS, Pasaribu S, Lubis CP. Status gizi dan infestasi cacing usus pada anak SD. FK USU: e_USU repository; 2004.

3. Rampengan TH, Laurentz IR. Penyakit infeksi tropik pada anak. Jakarta: EGC; 1993. 217-223. 
4. Saprasetya A, Widiastuti R, Arjadi F. Prevalensi infeksi soil transmitted helminth pada muridmurid SD di Desa Nusadadi, Kecamatan Simpiuh, Kabupaten Banyumas. Mandala of Health. 2005 Mei; 1: 1-5.

5. Dirjen Pengendalian Penyakit dan Penyehatan Lingkungan-Depkes Riau. Askariasis. 2008. [diakses 15 September 2008]. Diunduh dari : http: //www.pppl.depkes.go.id.

6. Gandahusada S, Pribadi W, Ilahude HD. Parasitologi kedokteran. Jakarta: Fakultas Kedokteran Universitas Indonesia; 1998. 8-10.

7. Rahayu SE. Keberadaan telur cacing parasit pada siswa SD di sekitar Instalasi Pengolahan Air Limbah (IPAL) Terpadu Kota Malang dan hubungannya dengan kepadatan telur cacing pada air limbah perumahan di IPAL Terpadu. Berkala Penelitian Hayati. 2006 [diakses 5 Maret 2008]. Diunduh dari : http: //www. PBjournal. discoveryinodesia.com.
8. Gusrianti. Pemeriksaan kotoran kuku murid SD Negeri No.15 Limo Kampuang Kabupaten Agam [skripsi]. Padang: Fakultas Kedokteran Universitas Andalas; 2001.

9. Riani. Identifikasi cacing pada pemeriksaan kuku terhadap 24 Siswa MIBU (Madrasah Ibtidaiyah Bustanul Ulum) Glengseran Kecamatan Panti Kabupaten Jember. 2008 [diakses 1 Desember 2008]. Diunduh dari : http : // www . digilib . unej.ac.id.

10. Agus H. Infeksi Ascaris lumbricoides pada murid kelas 1, 2, dan 3 SD Negeri 034 Kelurahan Meranti Pandak, Rumbai [skripsi]. Pekanbaru: Fakultas Kedokteran Universitas Riau; 2005.

11.Herison R. Infeksi Soil Transmitted Helminths pada murid SD Negeri 027 Labuhan Tangga Besar, Rokan Hilir [skripsi]. Pekanbaru: Fakultas Kedokteran Universitas Riau; 2008. 